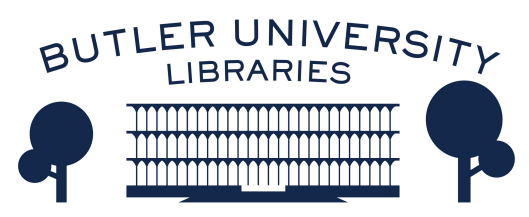

Journal of Hindu-Christian Studies

Volume 4

Article 3

January 1991

\title{
Protestant Bible Translations in India: An Unrecognized Dialogue?
}

John B. Carman

Follow this and additional works at: https://digitalcommons.butler.edu/jhcs

Part of the Religion Commons

\section{Recommended Citation}

Carman, John B. (1991) "Protestant Bible Translations in India: An Unrecognized Dialogue?," Journal of Hindu-Christian Studies: Vol. 4, Article 3.

Available at: https://doi.org/10.7825/2164-6279.1041

The Journal of Hindu-Christian Studies is a publication of the Society for Hindu-Christian Studies. The digital version is made available by Digital Commons @ Butler University. For questions about the Journal or the Society, please contact cbauman@butler.edu. For more information about Digital Commons @ Butler University, please contact digitalscholarship@butler.edu. 


\title{
Protestant Bible Translations in India:
}

\section{An Unrecognized Dialogue?}

\author{
John B. Carman \\ Harvard Divinity School
}

\begin{abstract}
DURING MY FIRST visit to Kyoto in the spring of 1980 , I was given the privilege of attending a meeting of the committee of scholars supervising one of the two series of translations of Shinran Shonin's works now appearing in English. Except for Dr. Minor Rogers, an American scholar of Shin Buddhism, and myself, all the other participants were Shin Buddhists belonging to the "Western Temple" branch of Shinran's followers. Dr. Dennis Hirota, who has contributed several of the draft translations, is a Japanese American. The rest of the group were Japanese. The procedure used by the committee to review a draft, line by line, and sometimes word by word, reminded me of many Christian projects of Bible translation and revision. At this meeting an issue arose that has recurred throughout this project: whether the Japanese term shinjin should be translated into English as "faith" or as "true mind," or simply be transliterated, remaining in the English version as shinjin. Anyone familiar with the history of Bible translations will be reminded of similar debates, which, like this one, spread from the committee room to a much broader discussion, sometimes going beyond a single religious community. Indeed, although this project has been conceived and carried out within a particular Buddhist community in Japan, it comes in response to a need felt by Shin Buddhists in North America, fewer of whom in each succeeding generation know enough Japanese to read the original texts. They live in a society, moreover, where "faith" is understood in a non-Buddhist context, whether Christian or secular. The committee meeting of Buddhists in Kyoto had to deal with the question of what "faith" means to people who speak English, which certainly includes the
\end{abstract}

question: what does "faith" mean to Christians?

Translations of scriptural texts, both those done by members of a religious community and those done by outsiders, constitute a large part of the data of the modern comparative study of religion. The focus of this short paper is not on translations as finished products but on some implications of the process of translating. I want to suggest that such translating provides a distinctive model for the contributions of scholars to interreligious dialogue. It is different from the model Father DeSmet has given us in the previous article on Robert de Nobili (or Nobili, as he often called himself) and also different from the models put forward by various others in Hindu Christian Dialogue: Perspectives and Encounters.

Nobili's accomplishments were remarkable. Without the Portuguese protection accorded earlier Roman Catholic missionaries on the coast of India, he managed to settle in Madurai, become fluent in three Indian languages (Tamil, Telugu, and Sanskrit), and become an acceptable conversation partner for many Brahmins. As Farther DeSmet shows, Nobili was able to utilize the concepts of Hindu philosophy to develop basic Thomistic arguments. Whether by the logical force of those arguments or by the force of his personality, he was able to persuade a number of Brahmins to become Christians, on a scale possibly unmatched by any other Christian missionary before or since. The forms of his persuasiveness were, however, not new. For more than a thousand years Indian philosophers of different religious persuasions had attempted 


\section{John Carman}

to convince one another in a process that required careful study of opposing positions before attempting to refute them. According to the hagiographies, the hero of a particular encounter sometimes received Divine aid. In one story it was the confidence generated in Rămannuja by a dream revelation that convinced his opponent to concede even before the day's debate began. ${ }^{1}$ Certainly Nobili possessed a large measure of such confidence, but it was not so much a belief in his own skill as confidence in a universal reason uniting human beings across linguistic, cultural, and religious barriers. He could afford to be patient because he believed that his debating partners would be convinced by their own reasoning.

DeSmet is not presenting his account for antiquarian reasons. For him Nobili is a model for modern Christian scholars who want to combine scholarship and evangelism in a scholarly dialogue, and he wants to affirm this model at a time when it is being challenged, even by some Roman Catholic priests and some Jesuit theologians in India. DeSmet quotes a statement of Jacques Dupuis: "Neither on one side nor on the other does...[dialogue] tend to the 'conversion' of one partner to the religious position of the other." DeSmet disagrees, and he also seems uncomfortable with Francis' conclusion that Nobili's "belief in the universality of reason is premodern and...divides him from most modern missionaries and most modern scholars of religion." DeSmet believes that he and his colleagues are still trying to follow Nobili's example. In his final paragraph DeSmet states that what is most worthy of imitation in Nobili's approach to dialogue is his "respect for other minds' freedom of decision." The entire essay seems to me also to imply that dialogue is legitimate, and even necessary, in the evangelistic effort to seek conversion to Christ. Thus he thinks that Dupuis goes too far in saying that "Interreligious dialogue constitutes a mutual evangelization under the impulse of the Spirit."2

This "mutual evangelization" is sometimes referred to in recent discussion as the aim of dialogue. For those who hold this view, scholarly dialogue is important, but only if such dialogue goes beyond the scholarly aim of un- derstanding. The contrasting view, voiced by Robert Baird on behalf of many contemporary Western scholars in religion, is that scholarly study of religion should be completely separated from evangelism. (See Hindu-Christian Dialogue, ed. by Harold Coward, Orbis, 1989, pp. 217-229).

The model of scriptural translation I want to commend lies somewhere in between these other approaches, whether or not we consider any of them "premodern." Protestant missionary translators shared Nobili's confidence in a universal human capacity animated by the Holy Spirit. They believed, however, that this was the ability; not to win a logical argument, but to understand and respond to the Biblical message. The act of translating assumes the capacity of those who read the translation to understand its meaning, and in the era of the printing press this has generally meant the possibility of reading it on one's own without the accompaniment of an approved commentary.

What is equally remarkable is the involvement of non-Christian scholars in the process of translation. They are rarely given much credit in Western missionaries' reports on these translations; in many cases we do not even know their names. Perhaps the most striking use of such Brahmin assistants was in William Carey's ambitious project to translate and print the Bible in all the principal languages of the East. ${ }^{3}$

Carey described his translation method in preparing the Bengali translation as follows:

I employ a pandit... with whom I go through the whole in as exact a manner as I can. He judges the style and syntax, and I of the faithfulness of the translation. I have, however, translated several chapters together, which have not required any alteration in the syntax whatever; yet I always submit this article entirely to his judgment. I can also, by hearing him read, judge whether he understands his subject by his accenting his reading properly and laying the emphasis on the right words. If he fails in this, I immediately suspect the translation... 4 
More information is given in an anonymous New England Unitarian pamphlet of 1825 , drawing on a letter from William Ward and from the ninth memoir of the translator, published in 1823. The Sanskrit and Bengali translations were done by William Carey before he moved to Serampore and joined Joshua Marshman in teaching at the College of Fort William. The senior Sanskrit pandit called Dr. Carey's attention to the "learned men...from the different provinces of India" who had ap: plied for work at the College. Carey engaged these men, as fast as they were brought to him; and he put

the Sanskrit Bible, as the original from which they were to translate, into the hands of each of them.

Each Pandit...began to render the divine word into his native dialect....assisted...by hints and directions from two learned Hindoos, who were prepared by Dr. Carey...by having read the proofs of the Sanskrit and Bengalee with the Doctor. 5

Both the translator and one of the two more experienced assistants went over the first and second proofs to bring the translation as close as possible to the original Sanskrit. The translator then took the third proof to Dr. Carey, and the two of them went "over as many more proofs...as the Doctor thought to be necessary." There was also frequent consultation among the various translators. Most of the "eighteen or twenty Pandits" knew Sanskrit and either Bengali or Hindi. They were thus able easily "to converse with one another, and with the European translator," "consulting one another" about "any passage or phrase" whose meaning "they might not fully comprehend."6

All of these translations were done with great care. The shortest period for translating any version of the New Testament was seven years, and the translation into two South Indian languages and into Chinese took twelve years. Even so,

"says Mr. Ward, we are perfectly aware that they will be improved in every new version, as all the European versions have been; and we court the severest scrutiny, if it be honest and candid. As a proof of which, we have invited criti- cism, by a publick advertisement circulated throughout India."

The criticism came a few years later, from very close by, and it concerned the first and most widely used of the translations, William Carey's Bengali New Testament. The criticisms were of at least three kinds, and were directed both at Carey's translation and at another translation by a "Mr. Ellerton." First, there were a number of mistakes with Bengali idiom, some rather embarrassing. Second, there were some unwarranted additions of words not in the Greek text, for theological reasons. Third, the translations relied on the Greek text used for the Authorized ("King James") Version rather than on the recent critical text of Griesbach. Two of the younger Baptist missionaries at Serampore, William Yates and William Adam, joined with Ram Mohan Roy in working on a new translation. A dispute arose as to whether dia in the Gospel of John 1:3 should be translated with the Bengali preposition meaning "by" or with the word meaning "through." Yates defended the reading that the world was created "by the Logos," used in the earlier translations, and withdrew from the project when Adam and Roy urged "through the Logos," because of its implications in favor of a Unitarian position. In fact, some time later William Adam became a Unitarian, and he resigned from the Baptist Missionary Society.

This translation project was unlike those that Carey had supervised, where only the missionaries knew Greek and where there was a stricter division of labor: the pandits responsible for the right linguistic form and the missionaries for the right theological content. Roy was not a professional pandit, but knew both Sanskrit and Greek; Yates and Adam knew Bengali; all three were equal partners regarding the theological import. Indeed, it turned out that Roy played a decisive role, and Adam accepted Roy's interpretation, not in the first place of Hindu doctrines, but of the meaning of the Greek text of the New Testament.

The work on the Marathi translation "was in the first instance done by Pandit Vaijanath," with the Serampore trio of missionaries serving as the editorial committee. Carey wrote: 
Whatever helps [sic] we enjoy, I have never yet suffered a single word or a single mode of construction to pass, without examining it, and seeing through it. Brother Marshman and I compare with the Greek or Hebrew, and Brother Ward reads every sheet.

The translation was a failure, however, for a reason the missionaries had not foreseen. Pandit Vaijanath spoke a dialect of a district far from the center of Marathi culture, so most of those in the Marathi area found it practically unreadable. ${ }^{9}$ While partial translations were later done by the first English and American missionaries in Maharashtra, the first complete translation of the New Testament adapted Carey's procedure. There were five American missionary translators, each responsible for one part but exchanging revisions on the other parts. Each missionary translator was "assisted by one or more pandit." The assistance was substantial:

The usual procedure was to give the sense to the pandit direct from the original; the pandit then wrote it in his own words. Very little was written by the missionaries themselves, and that little only with the utmost care to include the pandit's corrections of idiom and style. ${ }^{10}$

This Marathi New Testament was issued in 1826 , but it was immediately criticized as "stiff and obscure," and an English missionary, the Rev. William Mitchell, started a more idiomatic translation. By 1831 a committee was formed to supervise another translation of the entire Bible, which was published in one volume in 1855. One of the members of that committee was Captain J.T. Molesworth, who had supervised the creation of the first large scale Marathi dictionary, which was to prove useful, not only for Bible translations, but for much other literary work in Marathi, especially the development of Marathi prose. I note this work here, both because Bible translations and dictionaries were closely connected in many parts of India, and because the modern editor of the dictionary gives a brief biographical sketch of the team that produced it, which included not only Molesworth and two English colleagues, but also seven pandits; three of them translated English books on Mathematics into Marathi, and one did an anthology of Marathi poetry and translated several Sanskrit plays into Marathi. ${ }^{11}$ We shall return later to the significance of the other writings of Indian scholars participating in Bible translation.

Bishop Sabapathy Kulandran of the Jaffna Diocese of the Church of South India has written an interesting article about a particular Tamil translation produced during the $1840 \mathrm{~s}$ in his home city of Jaffna (northern Śri Lanka) in which the contribution of the missionary Peter Percival's Tamil native assistant was clearly major. Indeed, the Hindu biographer of Arumuga Navalar "says that the version turned out under Percival's supervision was really Navalar's handiwork." ${ }^{12}$ Kulandran, himself a Tamil Christian of the post-independence era, urges an intermediate position on the relative importance of theological content and linguistic style. In any case, as he points out, there were many others involved in the project besides the chief translator, Percival, a British Methodist, and his brilliant young Hindu assistant. "Jaffna at the time had a tremendous fund of scholarship to draw from, both... Western missionaries...and Jaffna-Tamils." ${ }^{3}$ After noting the names and accomplishments of the missionary scholars Kulandran goes on to describe the Tamil scholars and concludes,

Probably these and quite a few others among Tamils were constantly consulted. They are, however, not mentioned by name, as Western scholars of those days had a firm opinion that work of Eastern scholars could certainly be availed of, but that their names were scarcely worth mentioning. The record merely says that native pundits or assistants helped. ${ }^{14}$

Since Bishop Kulandran has been decidedly more positive about Western theology and Western missionaries than some other Tamil Christian scholars, his summation must be taken seriously. The attitude he describes is not confined to missionary scholars nor to the nineteenth century!

This translation, known as "the Tentative Version" because it was turned down by the committee in Madras for general distribution in South India, was itself the first Tamil trans- 
lation chiefly supervised by a committee. Unfortunately, whether because of the missionary attitude just described or for other reasons, we have no record of all the conversations in the committee or of what must have been daily exchanges between the English Protestant missionary and the Tamil Śaiva scholar, whose name came to be attached in the memory of Jaffna Christians to the "Navalar Bible."

Ârumuga Pillai, later called Nāvalar, "the Learned," lived from 1822 to 1879 . As a boy he studied Śaiva works in Tamil with his father, who was a Tamil poet. At the age of twelve he entered in the Wesleyan Mission School, where he started reading the Tamil Bible. He was only sixteen when he was appointed a teacher of Tamil, and when he was nineteen Peter Percival hired him to help translate various treatises and the Prayerbook, as well as to work on the new translation of the Bible. He worked with Percival for eight years, from 1841 to 1848. Already in 1842 , at the age of twenty, he joined with other Śaivas in responding to Christian missionary attacks, and he wrote an anonymous letter to the Tamil Christian journal in Jaffna in which he criticized the Christians' ignoring of the temple worship he found central to the Bible: "the missionaries had created a religion that their own scriptures did not support." The missionaries had indeed been brought by God, but that God was Lord Siva, who brought them to chastise the Tamil Saivas' in order to awaken them to the path revealed in the Veda and the Saiva scriptures (the Āgamas).

Navalar was not only a learned scholar and a gifted writer, but he was also a devout Saiva who became a theologian and reformer. After finishing the translation and accompanying Percival to Madras to help plead for its publication, he left his mission employment, started a Śaiva school, and used the methods of missionaries to promote a revival of Tamil Śaivism. ${ }^{15}$

Navalar's Hindu reform can be compared with that of Ram Mohan Roy in Bengal thirty years before, for Roy had worked with the British Baptist missionaries at Serampore and had co-edited with Yates a harmony of the Gospels. When, however, Roy produced his own selective version of the Gospels, empha- sizing Jesus' ethical teachings and omitting the miracles, he was denounced by the missionaries and a series of acrimonious exchanges ensued. Both Roy and Navalar claimed that Christian missionaries were misinterpreting their own Scripture by neglecting its evident meaning. For Roy this meaning was the unity of God, and for Navalar it was the observance of temple sacrifice. In both cases these Hindu scholars, who had accepted the Protestant invitation to read the Bible themselves, were proposing a more Jewish interpretation than the orthodox Christian reinterpretation of the Jewish tradition.

$$
\text { * * * }
$$

It is clear that Hindu pandits had a major role in many of the Protestant translations of the Bible into Indian languages. It is not clear how many of the sometimes daily conversations between Western missionaries and Indian scholars touched on matters of theological import. Discussions of both grammar and literary style may well have had theological implications. Choices had constantly to be made between more philosophical, literary, or everyday terms. That most of these Indian contributors to the translation were Brahmins certainly gave a Sanskritic emphasis to official Christian language that has marked it ever since.

I should be pleased to hear if there are records of the actual conversations in the midst of the translating process. It is such conversations that I consider an unrecognized dialogue. What we do have are some accounts of long distance exchanges in journal articles on points of Christian polemic and Hindu response, and many of the participants in the translation projects also wrote other works that may reflect their point of view in such "dialogue."

In some cases the pandits may have been uninterested in the theological issues involved and concentrated on the best phrasing in their respective languages. Just as Carey involved himself in the literary form of the translation, however, so the Hindu scholars must have sometimes been concerned with questions of religious or historical or philosophical meaning, and often form and content would have been impossible to divide. Even if, which seems quite unlikely, only the Christian partici- 
pants in the translation process were concerned with the Text's religious meaning, the use of a language freighted with Hindu associations necessarily would involve questions about the Hindu as well as the Christian significance of a particular term in Bengali or Tamil, as well as the ramifications of the meaning of that term for many related terms.

The recent decision of one Shin Buddhist translation committee to transliterate shinjin while another translation series often translates shinjin as "faith" is strikingly parallel to the very first efforts by St. Francis Xavier, almost four hundred and fifty years ago, to translate Christian theological terms. After initially translating the Japanese word for God with the name of a particular celestial Buddha, Dainichi, Xavier changed his mind when he learned more about the Buddhist meaning of Dainichi and decided not to translate the Latin Deus but rather to use Japanese transliterations for Deus and fifty other Latin terms in the catechism. Roman Catholics did not translate the Bible in Japan, China, or India, but did translate the Catechism and the Lives of the Saints long before there were any Protestant Bible translations in Asia. In India Roman Catholic usage has continued to include many transliterated Latin terms.

Protestant translators have tried to translate as many words as possible. European Protestants have had the example of such translations into their own language and, despite a frequently gloomy view of the effects of sin on human mental capacities, they have generally expected to find resources in every human language for translating the "Word of God."

The translation of the words for God (Elohim, YHVH, and Theos) was a point of continuing controversy in many of these translations. Navalar used tevan (Sanskrit deva) instead of tampiran (the Absolute) or sarvesuran (Lord of All), used in previous translations. Those who disliked his choice said that he had promised his mother "not to teach the correct word 'Îswaran' (Lord) to the Christians." 16 It is true that in many parts of India, especially in the North, the word deva, which is the Sanskrit cognate of the Latin word deus, has been avoided because it refers to the many divine beings of the Vedas. In south Indian devotional movements, however, both Siva and Viṣnu are sometimes referred to by their respective followers as deva, in a sense synonymous to iśvara, meaning (Supreme) Lord. It has been suggested that if capital letters were introduced in Indian alphabets, the English distinction between "God" and "god" could be made; without the distinction, deva must necessarily remain ambiguous in Indian languages. ${ }^{17}$ Perhaps a more significant difficulty is that Christians are trying to use some generic word for deity in contexts where Hindus more frequently use a specific divine name, especially when suggesting the God above all gods. Like other problems of translation, however, this one may never be finally resolved. Indeed, it points to a basic problem of such translation: to find a familiar word that will convey a radically new insight, which includes a new understanding of that very word.

Once a translation has been made it constitutes a new sacred language for those who use it in worship and meditation, and there has therefore often been great resistance to any new translation. This was a major reason why the philosophically more sophisticated Tamil translation of Arumuga Navalar and Peter Percival was turned down. In this respect as in many others, William Carey had a remarkably clear view of translation as a continuing process.

He never fell into the error of supposing that there could be any finality in the work which he accomplished. $\mathrm{He}$ claimed that he never sent a fresh edition to the printers without a thorough revision. He made plans for others to continue the work of translation. In the college which he founded he made provision for the teaching of Hebrew, Greek, and Latin to those who might later be translating the Scriptures into their mother-tongues. He prepared grammars and dictionaries in many of the languages into which translations were made. He prepared copious notes for a Universal Dictionary of Oriental Language derived from Sanskrit, from which a vocabulary in manuscript form is still kept at the college. ${ }^{18}$ 
It appears, however, that neither he nor any other missionaries engaged in translation saw the full significance of the daily experiments in what, I suggest, were an important form of interreligious dialogue. Certainly Carey and other missionaries prayed that their Hindu assistants might grasp the message that they were helping to translate, and indeed some of them did at some point become Christians. Even the most celebrated non-converts, Ram Mohan Roy and Arumuga Navalar, were influenced by their study and had great respect for the Bible. It was the orthodox Christian interpretation of the Bible that they both, in very different ways, rejected. As part of his monotheistic reform of Hinduism, Roy wanted to make his edited version of the teachings of Jesus available to his countrymen. Navalar tried, through his school, his sermons, and his many publications, to revive the personal and collective worship of Lord Śiva and to give support for the social institutions of the community of Siva's devotees.

Protestant missionaries believed that the Holy Spirit would aid in the understanding of the bible and induce conversion, but they also thought that there was a preliminary level of understanding possible without conversion-otherwise all those Hindu pandits would have been unable even to assist in translation. They generally maintained that the chief gift of the Holy Spirit would be conversion, and they would usually not admit as theological discussion partners, or as personal friends, those who had not confessed their faith in Christ. There were some exceptions, and perhaps there were many more conversations, sometimes focussing on a verse of Scripture, sometimes on a painful or joyous circumstance, which were never recorded.

In some respects the growth of more liberal views among Christians has altered the situation, but by the time Protestant theology had changed, the Bible translations had been made, and further revisions of these translations involved more Indian Christians, but fewer Hindus. Hindus have continued to encounter the Bible, both in English, as a part of their education in English in mission schools, both Catholic and Protestant, and in the various Indian vernaculars. They have in many cases also developed a new understanding of their own scriptures, on the model of the Protestant Bible, as printed books available in their own language. There have been learned exchanges between Hindu and Christian scholars about these scriptural texts, but the availability of both Hindu and Christian scriptures has also vastly broadened the range of participants in discussions within as well as between these religious communities.

These Christian translations of the Bible occurred during the same period when Hindu scriptures were being translated from Sanskrit into Indian regional languages and also into English and when older vernacular versions of the Hindu epic were being printed so that they could be read by the increasing number of Indians who were learning how to read. Hindus and Christians were both involved in these translations of Hindu scripture. The most daring translations of Hindu scripture were those of the Vedas, since they were not supposed even to be heard by the majority of Hindu men, or even, according to some authorities, by Brahmin women. Ram Mohan Roy's translations of the Upanishads were intended to break the veil of secrecy in order to reveal the truth of ancient Hinduism to Hindus knowing their own religion only in a later degenerate state. Roy had already completed his translation of four Upanishads when he joined in the revision of Carey's Bengali New Testament. The motivations of the Christian missionaries engaged in translating or publishing Hindu scriptures were not always clear. I suspect that Carey's motivation was complex, including both making Hindu classics available in a language everyone understood and exposing what he considered the insufficiency and contradiction of the books Hindus considered sacred. It is possible that there was also some ambiguity in the motivations of the Hindu translators and typesetters working on both Christian and Hindu translation projects.

I cannot recommend either the present or the past situation of Protestant Bible translation as a model for future dialogue, but there is a suggestive feature of the translation process, precisely when it is at its most preliminary 
stage: individuals meet around a text that is regarded by some of those present as more than a human text, as a Divine communication or an agent of Divine intervention and conversion, as a sign of Divine grace. By the process of translation a new text is created, and possibly an old scripture is transformed. Those present are usually aware of the difficulties and the risks of translation, and some might be skeptical about the possibility of genuine translation. With different kinds of expertise and different motivations the process of translation gets underway. The process requires that what is most solemn and sometimes most secret in a religious community be brought outside and openly discussed. The normal rules of moral or doctrinal qualification are suspended, and those to whom the message is addressed become the judges, not only of its intelligibility but of its elegance. If it is to be "scripture" in an Indian context, it must express the truth, but do so in an appropriately beautiful form. Then even those initially unconvinced of its truth may be attracted by its beauty.

Translating done cooperatively by those from different cultural and religious backgrounds is a rare opportunity in human interaction: working together in a way that has some rules but is not totally defined, working together towards a goal that may be diversely viewed by different participants. Such cooperation is not dialogue in Nobili's sense, where each side seeks to convince the other of the truth of its theological position. Translating together does not require all the participants to set forth systematically their respective beliefs, for the focus is not on the beliefs of the participants but on the meaning of a sacred text in a new language and a new religious context. Those from outside the community that has considered the text sacred may view that text in a variety of ways, as other people's scripture, as a piece of great literature, or even as a relic of a vanishing culture.

We should now be concerned, not only with the forgotten or unrecognized dialogues of the past but also with the ambiguous present and uncertain future of our scholarship. "Native assistants" may now be called "indigenous informants," but they ought to be recognized as respected teachers and colleagues in a common enterprise. Whether such cooperative scholarship, especially collaboration or translation, constitutes "dialogue" depends not only on the definition of dialogue but on the specific circumstances of each project. In any case we need more dialogical scholarship, more recognition of the diverse vantage points and distinct gifts of the different members of the project, but we need not allow the distinctive meaning of a particular text to disappear into a kaleidoscope of perspectives. Such scholarship should be aware of institutional constraints and a variety of social pressures. It does matter who is paying the salaries or providing the grant, but neither our intellectual freedom nor our moral responsibility are removed by the social reality of power. Perhaps one reason why Indian scholars continue to be more generous than some scholars in the West to so-called "Orientalism," is their understanding of both the necessary connection and the crucial distinction between scholarship and power.

Translation and retranslation of sacred texts continue to be important parts of both religious and secular scholarship around the world. In many cases translating can be far better done cooperatively and in some cases it may involve some supervising committee and even larger circles of reception and response. The explicit doctrines and the implicit values of diverse cultures are inevitably part of the discussion, as well as those distinctive possibilities and limitations in a particular language that makes it so difficult to separate form from content, which is what all translation involves. The excitement of relatively successful translation can even lead to the recognition of a new scripture, i.e., a text recognized as sacred in a new linguistic setting. The inevitable failures in all translations should remind us that translating is a continuing enterprise, is in some sense revised in every sermon or scriptural discourse, with results that may go beyond scholarly understandings: an ancient oracle may be heard as a new angelic voice, a call to repentance or a stimulus to insight.

A few weeks ago here in Cambridge we held a meeting of the group preparing a Tamil text and English translation of the Tiruvaymoli 
for the Harvard Oriental Series. This sacred poem, called the "Tamil Veda" by South Indian Vaishnavas, has had several partial and a few complete translations in the past century. All of them have had to face the problem of conveying both the literal meaning of the verses and the rich layer of meanings that the commentators have found implicit in the text. Since those meanings are considered by some to be the secret lore of committed members of the community, there are further problems in preparing a translation. Those problems do not take away the challenge of once again attempting the impossible, which in this specific case means translating Tamil poetry into English verse.

The three translators (A.K. Ramanujan, Vasudha Narayanan, and Francis X. Clooney. S.J.) have already exchanged partial drafts. A much larger number of scholars in both India and the United States have already contributed to the preparation for this project. We hope that that many more will respond to the translation when it is published, for translating is never finished, and the meaning of this sacred scripture is never exhausted. Will the translation necessarily lose the sacredness inherent in Nammâlvar's "sweet Tamil" verses? Is their true significance only comprehended by the initiated servants of the Lord whom the poet is praising? Those remain open questions, like the meaning of Deus in Japanese, tevan in Tamil, and shinjin in English. They deserve to be the subject of an open discussion, which we may call an interlinguistic or an intercultural or an interreligious dialogue, dialogue that enlivens both the composition and the reception of new translation.

Postscript. Since I have touched on a number of topics that I have not been able to develop adequately, I have asked Francis X. Clooney, S.J., and D. Dennis Hudson to append some brief comments. I am grateful to both of them for their generous response and I want to thank Dr. Hudson also for providing other materials for this essay. Much more needs to be said in comparing the approaches in Tamilnadu of Roberto de Nobili in the seventeenth century with those of the German Protestant Bible translators in the eighteenth century. I should be pleased to have further information about the topic on which I had originally planned to focus: conversations between Hindu pandits and the Christian missionaries supervising their translations.

\section{Footnotes}

1 I have summarized this story on pp. 41-42 of The Theology of Rāmānuja (New Haven: Yale University Press, 1974).

2 See Richard DeSmet's preceding article, " $R$. de Nobili as Forerunner of Hindu-Christian Dialogue."

3 See Appendix 1.

4 J.S.M. Hooper, Bible Translation in India, Pakistan, and Ceylon, 2nd ed. revised by W.J. Culshaw (London: Oxford University Press, 1963), p. 33. The work of Carey that is quoted is not stated.

5 Anonymous member of the Unitarian Society, Appeal to Liberal Christians (Boston: Office of the Christian Register, 1825), p. 40.

6 Ibid., pp. 40-41.

7 Ibid., pp. 41-42.

8 Hooper, p. 104.

9 Ibid., pp. 104-105.

10 Hooper, pp. 109-110.

11 N.G. Kalelkar, Preface to Reprint of Molesworth's Marathi-English Dictionary (Poona: Shubhada-Saraswat, 1975), pp. 19-20. I am indebted to Dr. Gary Tubb for calling Molesworth's Dictionary to my attention.

12 The Right Rev. Sabapathy Kulandran, "The Tentative Version of the Bible or 'The Navalar Version,' " in Tamil Culture, VII., (1958): pp. 229-50, p. 245.

13 Ibid., p. 235.

14 Ibid., p. 236.

15 I am indebted to Dennis Hudson for permission to use his unpublished article, "Tamil Hindu Response to Protestants among Nineteenth Century Literati in Jaffna and Tinnevelly."

16 Kulandran, p. 242.

17 A comment on this topic by Thomas Candy, one of Molesworth's colleagues, in his introduction to the English-Marathi Dictionary, is of considerable interest, not least because it was written at the same time Navalar and Percival were finishing their Tamil translation.

[G]enerally when a Maratha uses that word [deva], he thinks of some village god, some local idol, or red painted stone, and rarely of the Supreme Being: nor has the language as yet capitals, like our own, or an article like the Greek, to mark the distinction. After 


\section{John Carman}

all, as capitals are now being introduced into Maratha deva thus written will be the best term, by which to render the word God.

J.T. Molesworth and T. Candy, $A$ Dictionary of English and Marathi, compiled for the Government of Bombay (Bombay: American Mission Press, 1847).

18 Hooper, pp. 109-110.

\section{Appendix I}

There exists some significant information about a few of these pandits involved in the Serampore translations.

Rāmrăn Basu was a non-Brahmin scholar who worked with Carey even before Carey moved to Serampore (i.e., before 1800), and helped with the Bengali Bible translation. Basu also wrote on his own an early work on monotheism and a later critique of Brahmins. He was one of the first Indian language teachers (munshis) hired by the British East Indian Company College of Forth William (1801).

Jayagopāl Tarkalānkār was sought out by Carey in 1805 to teach Sanskrit and later edited the Bangali journal started in 1818 by the Ser- ampore Baptist missionaries. He re-edited Carey's publication of the Bengali version of the Mahābhärata and Rāmāyana. He was later appointed Professor of Literature at the Sanskrit College in 1824.

Mṛtyuñjay Vidyālañkăr was Carey's pandit, employed at College of Fort William in 1801. He wrote several books "at Carey's suggestion," including a translation of Hitopadesa from Sanskrit to Bengali in 1808. $\mathrm{He}$ is the presumed author of a later anonymous attack from a conservative Hindu perspective on the theology of Ram Mohan Roy.

I am indebted for this and other information about the Serampore missionaries and Ram Mohan Roy to Mr. Brian Hatcher, now a Harvard Ph.D. candidate in the Study of Religion writing his dissertation on the mid-nineteenth century Bengali educational reformer, Iśvaracandra Vidyāsāgar. The information about these pandits is from their biographies in Bengali. Some information can be found in various surveys of Bengali literature, such as S.K. De, Bengali Literature in the Nineteenth Century and Sukumar Sen, History of Bengali Literature. 